\title{
Influence of Cultivation Technology on the Productivity of Spring Wheat and the Humus State of Southern Carbonate Soils of Northern Kazakhstan
}

\author{
K. Kunanbayev ${ }^{1 *}$, G. Churkina' ${ }^{1}$, V. Filonov ${ }^{1}$, M. Utebayev' ${ }^{1}$, I. Rukavitsina ${ }^{1}$ \\ 1 Scientific Production Center of Grain Farming named after A.I. Barayev, Shortandy 1, 021601, Akmola Region, \\ Kazakhstan \\ * Corresponding author's e-mail: k.kunanbaev@gmail.com
}

\begin{abstract}
Intensive use of the chernozem soils of Northern Kazakhstan since the development of virgin lands has led to soil erosion and loss of humus. Since 1954, according to researchers, 1.2 bln tons of organic matter have been irretrievably lost. During this period, the methods of tillage have changed significantly from surface to subsurface tillage, which led to a change in the method of accumulation of organic residues in the soil. The purpose of this study was the short-term monitoring of spring wheat cultivation technologies to observe their influence on crop productivity and soil agrocenosis. A virgin plot was used as a standard of soil fertility. Determination of nutrients in the soil was carried out by using the method of "wet chemistry" with spectrophotometric termination. An infrared analyzer was used to assess the grain quality. The identification of soil microorganisms was carried out on nutrient microbiological media, such as meat-and-peptone agar, starch-and-ammonia agar, and CzapekDox agar. The results of three-year studies showed that the humus content in the variants with permanent wheat decreased to $3.26-3.38 \%$. The greatest decrease in humus content was observed in the two-field grain and fallow crop rotation $(2.48 \%)$. The decrease in the amount of humus occurred as a result of insufficient intake of plant residues and mineral fertilizers. The content of nitrate nitrogen and mobile phosphorus in virgin soil is low. Soil micromycetes dominate on virgin lands, whereas ammonifiers and immobilizers dominate on cultivated soils. The high level of carbon dioxide emissions on virgin land $\left(3.0 \mathrm{C}_{2} \mathrm{~kg} / \mathrm{ha} / \mathrm{hour}\right)$ is due to the presence of a large amount of plant biomass. The most optimal variant out the considered technological backgrounds from the point of view of increasing yields up to $15.8 \mathrm{c} /$ ha and preserving soil fertility ( $3.26 \%$ humus content) is the cultivation of permanent wheat with the introduction of fertilizers and herbicides. The use of two-field grain and fallow crop rotation leads to irreplaceable losses of organic matter $(2.48 \%)$.
\end{abstract}

Keywords: southern carbonate chernozem, spring wheat, humus, humus group composition, nitrogen, phosphorus, the number of soil microorganisms, soil respiration.

\section{INTRODUCTION}

In modern agriculture, the prevention of further loss of humus is the most important agronomic goal. Organic matter is increasingly regarded as an indicator of soil quality, which is one of the components of the stability of the biosphere. Destruction of the arable soil layer is the main cause of organic matter loss [Liaudanskiene et al., 2021]. The current state of arable land in Northern Kazakhstan is the result of the use of the land since its development [Kunanbayev et al., 2019]. Plowing and long-term agricultural use of chernozems are accompanied by a noticeable decrease in the content of humus reserves. Thus, during the period of exploitation of virgin lands from 4.3 billion tons of humus reserves in the arable layer, 1.2 billion tons, or $28.35 \%$, were irretrievably lost [Kunanbayev, 2017]. These losses are the result of mineralization of organic matter, carbon removal from crops, wind, and water erosion. Long-term studies conducted by scientists of the Institute on the southern chernozems of Northern Kazakhstan have shown that over 
30 years, the loss of humus from the $0-20 \mathrm{~cm}$ soil layer amounted to $20 \%$ in permanent fallow, $17.4 \%$ in grain and fallow crop rotation, $7.2 \%$ in six-field grain and fallow crop rotation, $4.6 \%$ in permanent wheat crops. The replacement of pure fallow with an annual crop contributed to reduced loss of humus by $5.6 \%$.

Humus is one of the most important components of the soil, determining the level of natural fertility, saturation with mineral elements for plant nutrition, as well as determining the physicochemical properties of the soil. In this regard, humus is constantly in the focus of attention of researchers and farmers. In Northern Kazakhstan, the attention to humus is caused by the introduction of resource-saving (minimal, zero-waste) farming systems, where plant residues accumulate in the upper soil layer. The issues of humus state, mineral nutrition, and microbiological activity were studied on three technological backgrounds: virgin soil, permanent wheat (minimal tillage), as well as two-field grain and fallow crop rotation (intensive tillage).

The main reason for the decrease in humus content during the development of virgin lands is a change in the composition of the source of organic matter, a decrease in the number of plant residues entering the soil when the natural biocenosis changes to agrocenosis, and an increase in its mineralization under the influence of intensive tillage, etc. [Ershov, 2004; Titova and Kogut, 1991; Vasiliev et al., 2004]. The decrease in the content and the rate of loss of organic matter depend on the nature of agricultural use, as well as physical, biological, and chemical characteristics of the soil [Ayupov et al., 2009; Polupan 1986]. Under the conditions of increasing intensification of agricultural production, the use of new types of crop rotations, and processing technologies, the primary goal is to reduce the loss of organic matter, especially its labile (mobile) part, which is a source of formation of stable humus substances. In this case, the problem of preserving fertility and increasing soil productivity should be solved by improving its agrophysical properties via increasing the intake of organic matter.

Despite numerous studies on the organic matter of the soils of Kazakhstan, the issues of humus formation under the conditions of anthropogenesis, where the agricultural use of soils is one of the main factors of soil formation, have not been sufficiently studied [Kenenbayev and Yesenbayeva, 2020; Saparov et al., 2019; Toktar et al., 2019].
On the basis of the above, the study aimed to assess the impact of wheat cultivation technologies on the humus state, soil microbiota, mineral nutrition, and crop yield.

\section{MATERIALS AND METHODS}

The study was carried out in 2018-2020 at the field stations of the Research and Production Center of grain farming (NPTsZKh) named after A.I. Baraev. The stations are located on the territory of the Damsinsky settlement of the Shortandinsky district of the Akmola region.

The object of the study is the southern carbonate low-humus chernozem of heavy granulometric composition formed on carbonate loam-like loams. It is distributed in Northern Kazakhstan on an area of 3.5 million ha. Large arrays of these soils are located in the Akmola region (up to $66 \%$ of the area of the southern chernozem subzone).

The soil section 730-89 was established to describe the characteristics of typical southern carbonate chernozem. The site itself is a flat plain with a homogeneous soil cover. Blurry spots of carbonates at a depth of 55-90 cm, wedges (cracks) drop to $117 \mathrm{~cm}$, gypsum in the form of scales occurs from $130 \mathrm{~cm}$.

The thickness of the humus horizon $(\mathrm{A}+\mathrm{AB})$ is $46 \mathrm{~cm}$. The color is dark gray with a brownish tinge, the structure is finely lumpy. A characteristic feature of soils is an increased content of carbonates and boiling of $10 \%$ hydrochloric acid solution from the surface or very close to it. The humus content in the soil layer 0-20 $\mathrm{cm}$ is from 4.0 to $6.0 \%$, gross nitrogen content equals $0.3-0.4 \%$, and gross phosphorus content is $0.14-0.20 \%$. The absorbed complex is dominated by calcium (up to $80 \%$ ) and magnesium (11\%). The increased content of carbonates in the upper horizon (about $4.0 \%$ ) determines the alkaline $\mathrm{pH}$ of the medium ( $\mathrm{pH} 7.5-8.5)$.

The southern carbonate chernozems of Northern Kazakhstan have high agrochemical indicators and are favorable for the cultivation of agricultural plants.

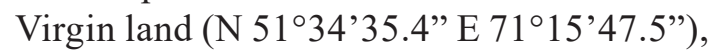
where the soil samples were taken, is a steppe zone with a predominance of grass and grain vegetation (Table 1). It is a reference for comparison with the soil in the arable land. Virgin soil is characterized by average indicators of potential fertility. 
Table 1. Statistical indicators of a typical section of southern carbonate chernozem, $0-20 \mathrm{~cm}$ layer

\begin{tabular}{|c|c|c|c|c|c|c|}
\hline Indicators & Humus, $\%$ & $\mathrm{~N}_{\text {gross }} \%$ & $\mathrm{R}_{\text {gross, }} \%$ & $\begin{array}{c}\text { The sum of the absorbed bases } \\
\mathrm{mg} \times \text { eq per } 100 \mathrm{~g} .\end{array}$ & $\mathrm{CO}_{2,} \%$ & $\mathrm{pH}$ \\
\hline $\max$ & 5.32 & 0.28 & 0.18 & 35.2 & 3.40 & 8.40 \\
\hline $\min$ & 3.00 & 0.15 & 0.09 & 25.9 & 0.30 & 7.70 \\
\hline $\mathrm{M}$ & 3.90 & 0.22 & 0.14 & 31.5 & 1.88 & 8.10 \\
\hline $\mathrm{Q}$ & 0.48 & 0.03 & 0.02 & 1.81 & 0.56 & 0.14 \\
\hline$\pm \mathrm{m}$ & 0.05 & 0.003 & 0.002 & 0.25 & 0.08 & 0.02 \\
\hline $\mathrm{V}, \%$ & 12.4 & 12.0 & 10.9 & 5.74 & 30.1 & 1.7 \\
\hline $\mathrm{P}, \%$ & 1.4 & 1.4 & 1.2 & 0.8 & 4.3 & 0.2 \\
\hline $\mathrm{n}$ & 80 & 77 & 81 & 51 & 49 & 75 \\
\hline
\end{tabular}

The studies with wheat crops were carried out at the long-term stations of the Institute. The experiment with permanent sowing of wheat without the use of chemicals was established in 1961 ( $\left.\mathrm{N} \mathrm{52} 32^{\prime} 53.65^{\prime \prime} \mathrm{E} 71^{\circ} 1^{\prime} 38.26^{\prime \prime}\right)$, and the experiment with the use of herbicides and nitrogen-phosphorus fertilizers (N 51 32 '54.83" E $\left.71^{\circ} 4^{\prime} 23.22^{\prime \prime}\right)$, as well as two-field grain and fallow crop rotation (N 51 33 '51.40” $\mathrm{E}$ 71'4'38.63”), were established in 1984. Crop rotations have been monitored since 2000 [Akhmetov, 1988; Karbozova-Saljnikov et al., 2004; Suleimenov et al., 2005]. The soil samples taken from a virgin plot were used as a control.

Mineral fertilizers were applied annually in rows when sowing permanent wheat at a dose of $\mathrm{N}_{30} \mathrm{P}_{20} \mathrm{~kg}$ per ha. In the wheat by fallow variant, only phosphorus fertilizers were applied at a dose of $\mathrm{P}_{20}$ in rows during sowing. From mineral fertilizers, ammonium nitrate (N -34.4\%) and ammo-

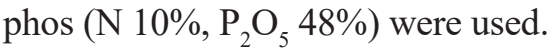

The variety of spring soft wheat Akmola 2 was sown. This is a medium-ripened, steppe ecotype, drought-resistant variety. The recommended agricultural machinery was used.

The determination of the content of nutrients, humus, and its group composition was carried out in the accredited agrochemical laboratory of the NPTsZKh named after A.I. Baraev annually from 2018 to 2020 . The data for three years were averaged.

Mobile phosphorus was determined by using the Machigin method. This method is based on the extraction of mobile phosphorus compounds from the soil with a solution of ammonium carbonate at a concentration of $10 \mathrm{~g} / \mathrm{dm}$ with a soilto-solution ratio of 1:20 and subsequent determination of phosphorus in the form of a blue phosphorus-molybdenum complex on a spectrophotometer [Mineev, 2001]. The extraction of nitrates from the soil was carried out with a solution of potassium chloride, subsequent reduction of nitrates to nitrites with hydrazine in the presence of copper as a catalyst, and photometric determination of them in the form of a colored diaza compound [Mineev, 2001]. The content of soil organic matter was determined using the method of I.V. Tyurin [Mineev, 2001]. The method is based on the oxidation of organic matter with a solution of potassium bicarbonate in sulfuric acid and the subsequent determination of trivalent chromium equivalent to the content of organic matter on a photoelectrocolorimeter. The determination of nutrients was carried out on a spectrophotometer (Cary 50, Varian). Determination of the group composition of humus was conducted with the accelerated pyrophosphate method according to Kononova and Belchikova [Mineev, 2001]. Extraction of humic acids was carried out with a solution of sodium pyrophosphate, then everything was well mixed and left for 16-18 hours. The next day, a saturated solution of sodium sulfate was added to the flasks to coagulate silty particles and accelerate filtration. The substance was well mixed immediately before filtration and filtered through a simple paper filter with a diameter of $15-17 \mathrm{~cm}$. The final determination was carried out by titration with Mohr's salt.

The protein content was determined in whole grains using an infrared (IR) analyzer (InfraLUM FT-10, Russia) (ST RK 1564-2006 [Committee for Technical Regulation and Metrology, 2006]), the weight per bushel was determined on a 11 grain unit scale $(\mathrm{PH}-1)$ (State Standard (GOST) 10840-64 [Committee of Standards, 2001a]). The mass of 1,000 grains was estimated by weighing two samples of 500 grains for each sample. Gluten washing was carried out on the MOK-3M device, 
the quality of gluten was determined on IDK3M (ST RK 1054-2002 [Committee for Technical Regulation and Metrology, 2002]). The vitreousness of the grain was determined on a DSZ-2M diaphanoscope with a cassette for 100 grains following (GOST 10987-76 [Committee of Standards, 2001b]). The selection of soil samples for microbiological analysis was carried out three times to a depth of $0-20 \mathrm{~cm}$. The following groups of soil microorganisms were determined: ammonifiers on meat-peptone agar (MPA), microorganisms using mineral forms of nitrogen on starch-ammonia agar (SAA), fungi on Czapek-Dox agar, cellulolytic microorganisms on Hutchinson medium (with filter paper as a carbon source). Identification of microorganisms was carried out using an Altami Bio digital binocular microscope (Russia). The emission of carbon dioxide (soil respiration), when studying biological indicators, was determined using the Karpachevsky method. Cellulolytic activity, considering the fiber-destroying properties of the soil, was determined by the application method. The severity of the processes of fiber breakdown was assessed on the following scale: $<10 \%$ : very weak, $10-30 \%$ : weak, 30-50\%: medium, 50-80\%: strong, > 80\% [Fedorets and Medvedeva, 2009].

In order to assess the degree of depth of microbiological processes in the soil, the mineralization coefficient $\left(\mathrm{C}_{\min }\right)$ was calculated, which shows the degree of development of the amylolytic part of the soil microbiocenosis and the coefficient of transformation of organic matter $\mathrm{C}_{\mathrm{pt}}$.

In order to find reliable differences between the studied variants, a one-factor analysis was carried out in the ANOVA software package at a confidence level of $95 \%$. If the difference between the averages of the two options is greater than or equal to the least significant difference $\left(\mathrm{LSD}_{05}\right)$, then these options differ significantly from each other.

\section{RESULTS AND DISCUSSION}

One of the main criteria for assessing soil fertility is the humus content and reserves. Longterm agricultural use of soils leads to significant changes in their properties, affecting the basis of soil fertility, the organic matter. In order to determine the actual changes in the humus state, its content in virgin soil and arable land with wheat cultivation was compared (Table 2).

The analysis of Table 2 shows that the highest content of organic matter was observed on virgin land $(4.91 \%)$ since virgin land is a natural object not involved in an agricultural turnover. Humus reserves are also relatively higher here, equaling $97.2 \mathrm{t} / \mathrm{ha}$. The preservation of organic matter on virgin land occurs due to the constant supply of plant mass. Very low reserves of humus $(<50 \mathrm{t} /$ ha) were noted in the variant of wheat cultivation in a two-field crop rotation. Fallow fields are still quite often used in production, which is due to their effectiveness in accumulating moisture, reducing infestation, and providing nitrogen. However, frequent mechanical fallow treatments lead to increased mineralization of organic matter, excessive accumulation of nitrogen, and its loss [Takata et al., 2007, 2008].

The humus content also decreased markedly in the variants of permanent wheat cultivation, where its losses amounted to more than $30 \%$ in the $0-20 \mathrm{~cm}$ layer. Here, a decrease in the content and reserves of humus occurs against the background of annual autumn and spring tillage of the soil and a decrease in the intake of organic matter from the agrocenosis used. The deceleration of the dehumification process and its stabilization on permanent wheat variants is explained by a decrease in the labile forms of humus and an increase in conservative, difficult-to-mineralize compounds. A sharp decrease in the humus content in the chernozem soils of Northern Kazakhstan occurs during the first ten years after plowing and in the following 20 years, there is a gradual

Table 2. Humus content and reserves in the $0-20 \mathrm{~cm}$ soil layer, $\%$ of the soil mass

\begin{tabular}{|l|c|c|c|}
\hline \multicolumn{1}{|c|}{ Variant } & Humus, $\%$ & Degree of humification, $\%$ & Humus reserves, $t /$ ha \\
\hline Virgin land & $4.91 \pm 0.25$ & $20.5 \pm 0.9$ & $97.2 \pm 2.4$ \\
\hline Perm. wheat without chemicalization & $3.38 \pm 0.42$ & $12.0 \pm 1.4$ & $66.9 \pm 5.7$ \\
\hline Perm. wheat with fertilizers and herbicides & $3.26 \pm 0.20$ & $12.0 \pm 1.4$ & $64.5 \pm 2.7$ \\
\hline Wheat on fallow land & $2.48 \pm 0.18$ & $13.0 \pm 1.8$ & $49.1 \pm 4.8$ \\
\hline Average & $3.51 \pm 0.50$ & $14.3 \pm 1.9$ & $69.4 \pm 9.6$ \\
\hline LSD $_{05}$ & 0.27 & 0.2 & 4.0 \\
\hline
\end{tabular}


stabilization of the humus state of the soil [Funakawa et al., 2004; Karbozova-Saljnikov et al., 2004; Pashkov and Baibusinova, 2017]. Thus, according to the State Research and Production Center of Land Resources (GosNPZEM), the humus content in the arable layer of $0-20 \mathrm{~cm}$ from 2000 to 2015 had decreased by $0.37 \%$ [Metodicheskoe rukovodstvo, 2004]. The equal content of humus in the variants of permanent wheat sowing is explained by the same flow of organic matter into the soil: the organic straw and weeds in the variant without chemicalization, and harvest straw in the variant with chemicalization. In the latter case, the reduction of contamination led to a doubling of wheat yields.

The lowest humus content $(2.48 \%)$ was noted on the variant of alternating wheat with pure fallow. In this case, the intake of organic matter from the crop (straw) into the soil was insufficient to balance the process of dehumification and reduce the mineralization of organic matter during intensive tillage within the fallow period. In general, it should be noted that the studied technologies of spring wheat cultivation have a significant impact not only on the total content of humus but also on its qualitative composition.

When virgin soil is turned into arable land, there is a sharp decrease in the content of semi-decomposed organic matter [Karabutov et al., 2019]. Due to the changes in the agrophysical properties of the soil, the air and water regime alters, which significantly activates the processes of mineralization of the semi-decomposed remnants of plant organic matter of the crop. This is accompanied by a decrease in all groups of humic substances, but the content of the fraction of free humic acids and associated with sesquioxides decreases to a greater extent. Considering the opinion of [Liaudanskiene et al., 2021], the fact that the fraction of humic acid interacting with sesquioxides is an indicator of the intensity of humus formation, it can be concluded that the process of humus formation weakens with the technologies of permanent and two-field grain and fallow cultivation of wheat. In turn, on virgin land, with a large volume of dead plant biomass, the transformation of organic matter is delayed and preserved in the form of detritus. At the same time, the plant mass formed in natural agrocenoses is produced, redistributed, and destroyed within the ecosystem [Koroleva et al., 2013]. Virgin soil is characterized by a sufficiently high content of labile humus. According to several researchers [Raiesi, 2021; Sharkov, 2010; Voltr et al., 2021], the decrease in fertility is not so much a decrease in total humus, as in the loss of labile forms of organic matter. The high content of labile humus in the virgin area indicates that some humic substances are involved in biological processes (Table 3).

According to the obtained data, during the development of virgin soils, the content of labile humus substances decreased by $40 \%$. This is because, during the cultivation of grain crops, the removal of nutrients by the harvest occurs due to the decay of the organic matter of the soil. At the same time, the total intake of plant residues into the soil is reduced by several times, in comparison with virgin land. It is noted that with prolonged use of southern chernozem in arable land, labile humus substances decrease relative to virgin soil, but their qualitative composition in the studied variants changed slightly.

The fulvate-humate type of soil prevailed in almost all variants. In contrast, the humatefulvate type was observed only in the two-field variant, which is due to the low content of humic and the predominance of fulvic acids. In the fallow field, dehumification and a sharp decrease in all groups of humus compounds are most clearly manifested. It should be noted that the humatefulvate type is not characteristic of southern carbonate chernozems. This boundary state $\mathrm{C}_{\mathrm{gc}}: \mathrm{C}_{\mathrm{fc}}=$ 1 is due to the low content of humic acids as a result of the mineralization of organic matter.

Permanent cultivation of wheat without the use of fertilizers against the background of a decrease in the content of organic matter in combination forms a deficiency of mineral nutrition.

Table 3. The group composition of humus on virgin land and arable land in a $0-20 \mathrm{~cm}$ soil layer, $\%$ of the soil mass

\begin{tabular}{|l|c|c|c|c|c|}
\hline \multicolumn{1}{|c|}{ Variant } & $\mathrm{C}_{\text {total }}$ & $\mathrm{C}_{\text {lab. }}$ & $\mathrm{C}_{\mathrm{gc}}$ & $\mathrm{C}_{\mathrm{fc}}$ & $\mathrm{C}_{\mathrm{gc}}: \mathrm{C}_{\mathrm{fc}}$ \\
\hline Virgin land & $2.87 \pm 0.33$ & $0.91 \pm 1.03$ & $0.59 \pm 0.05$ & $0.32 \pm 0.04$ & 1.84 \\
\hline Perm. wheat without chemicalization & $1.98 \pm 0.30$ & $0.43 \pm 0.05$ & $0.23 \pm 0.04$ & $0.20 \pm 0.02$ & 1.15 \\
\hline Perm. wheat with fertilizers and herbicides & $1.91 \pm 0.17$ & $0.42 \pm 0.05$ & $0.23 \pm 0.05$ & $0.19 \pm 0.05$ & 1.21 \\
\hline Wheat on fallow land & $1.45 \pm 0.36$ & $0.38 \pm 0.11$ & $0.19 \pm 0.04$ & $0.19 \pm 0.04$ & 1.0 \\
\hline LSD $_{0.5}$ & 0.20 & 0.06 & 0.04 & 0.02 & - \\
\hline
\end{tabular}


Table 4. Nitrogen and phosphorus content before sowing spring wheat, $\mathrm{mg} / \mathrm{kg}$ of soil

\begin{tabular}{|l|c|c|}
\hline \multicolumn{1}{|c|}{ Culture } & $\mathrm{N}^{-N_{3}}$ in the $0-40 \mathrm{~cm}$ layer & $\mathrm{P}_{2} \mathrm{O}_{5}$ in the 0-20 cm layer \\
\hline Virgin land & $2.5 \pm 0.2$ & $11.7 \pm 3.0$ \\
\hline Perm. wheat without chemicalization & $3.8 \pm 0.2$ & $15.0 \pm 5.0$ \\
\hline Perm. wheat with fertilizers and herbicides & $6.8 \pm 0.5$ & $39.0 \pm 6.4$ \\
\hline Wheat on fallow land & $24.4 \pm 3.0$ & $43.0 \pm 4.8$ \\
\hline Average & $9.55 \pm 4.7$ & $28.0 \pm 7.7$ \\
\hline $\mathrm{LSD}_{05}$ & 1.47 & 5.0 \\
\hline
\end{tabular}

Thus, the average content of nitrogen and phosphorus in the soil before sowing wheat on the variants without chemicalization amounted to only 3.8 and $15 \mathrm{mg} / \mathrm{kg}$, respectively (Table 4). The wheat yield in this case was formed only due to the reserves of nutrients of the soil itself. In the future, the level of productivity of grain crops in such agrocenoses will depend on the balance of the intake of nutrients with organic matter and the removal of the commercial part of the crop.

A different picture was observed for the nutritional regime of wheat on the variants with fertilization. With permanent cultivation of wheat using ammophos, the availability of nitrogen and phosphorus is improved by two or more times. This contributes to an increase in the supply of organic matter and its ability to maintain optimal water/physical and technological properties of the soil and, as a result, increase its fertility.

Mechanical fallow treatments activate the process of mineralization of organic matter, which, along with the use of nitrogen fertilizer in the composition of ammophos, contributes to a significant accumulation and increase in nitrogen content before sowing wheat, compared with the stubble background. When recalculating the content of $24.4 \mathrm{mg}$ of nitrogen in $\mathrm{kg} / \mathrm{ha}, 115 \mathrm{~kg}$ is obtained, which is enough to form a yield of $40.0 \mathrm{c} / \mathrm{ha} ; 62 \mathrm{~kg}$ of nitrogen is sufficient for the formation of the actual yield of $17.6 \mathrm{c} / \mathrm{ha}$. The nitrogen not used $(53 \mathrm{~kg})$ by the crop is mostly lost as a result of denitrification, erosion, and leaching. Long-term use of southern chernozem in the two-field crop rotation mode is impossible, since this is the way to a complete loss of fertility, and the preservation of fertility will require the use of special agrotechnical measures. Therefore, any farming system should ensure the replenishment of reserves of organic matter of the soil, the main source of mobile forms of humic acids.

The complex process of mineralization of organic matter begins with non-spore-forming ammonifying bacteria that destroy its available forms. It was found that the application of mineral fertilizers activated the development of ammonifying bacteria. Their number on the variant of permanent wheat in a layer of $0-20 \mathrm{~cm}$ reached 3.1 million CFU/g of soil (Table 5). The number of immobilizers on this variant increased 2.2 times in comparison with virgin land.

On the variants of permanent wheat without mineral fertilizers and herbicides and on fallow land, the activity of ammonifiers decreased to the level of virgin soil and amounted to 2.6 and 14.8 million CFU/g of soil, respectively.

The studied technologies did not have a significant impact on the species and numerical

Table 5. Influence of agrotechnical factors on the indicators of biological activity of the soil (field experiment, on average for 3 years)

\begin{tabular}{|c|c|c|c|c|c|c|}
\hline \multirow[b]{2}{*}{ Variants } & \multicolumn{4}{|c|}{ Soil microorganisms } & \multirow[b]{2}{*}{$\begin{array}{l}\text { Breakdown of } \\
\quad \text { fiber, } \%\end{array}$} & \multirow[b]{2}{*}{$\begin{array}{c}\mathrm{CO}_{2} \mathrm{~kg} / \mathrm{ha} \\
\text { hour }\end{array}$} \\
\hline & $\begin{array}{c}\text { Ammonifiers, } \\
\mathrm{mln} \text {. CFU/g } \\
\text { of soil }\end{array}$ & $\begin{array}{l}\text { Immobili } \\
\text { zers, million } \\
\text { CFU/g of soil }\end{array}$ & $\begin{array}{l}\text { Fungi, } \\
\text { thous. CFU/g } \\
\text { of soil }\end{array}$ & $\begin{array}{c}\text { Cellulose } \\
\text { destructive, } \\
\text { thousand } \\
\text { CFU/g of soil }\end{array}$ & & \\
\hline Virgin land & $2.7 \pm 0.1$ & $9.1 \pm 0.4$ & $16.8 \pm 0.8$ & $57.4 \pm 2.8$ & $44.7 \pm 2.2$ & $3.0 \pm 0.1$ \\
\hline $\begin{array}{l}\text { Perm. wheat without } \\
\text { fertilizers and herbicides }\end{array}$ & $2.9 \pm 0.1$ & $14.8 \pm 0.7$ & $9.8 \pm 0.4$ & $55.5 \pm 2.7$ & $21.5 \pm 1.1$ & $1.61 \pm 0.1$ \\
\hline $\begin{array}{l}\text { Perm. wheat with fertilizers } \\
\text { and herbicides and }\end{array}$ & $3.1 \pm 0.6$ & $20.9 \pm 1.0$ & $11.5 \pm 0.5$ & $76.4 \pm 3.8$ & $45.4 \pm 2.2$ & $2.61 \pm 0.1$ \\
\hline Wheat on fallow land & $2.6 \pm 0.1$ & $13.0 \pm 0.6$ & $9.7 \pm 0.5$ & $58.4 \pm 2.9$ & $39.5 \pm 1.9$ & $1.71 \pm 0.1$ \\
\hline \multicolumn{7}{|c|}{ Note: Perm. - permanent wheat (in Table 1) } \\
\hline
\end{tabular}


composition of soil micromycetes. In the fungi complex, all variants were dominated by the species Penicillium spp., Trichoderma spp., Aspergillus spp., Mucor sp. With the permanent cultivation of wheat with using fertilizers and herbicides, their number was 11.5 thousand $\mathrm{CFU} / \mathrm{g}$ of soil. A slight excess of micromycetes was noted on virgin land, equaling 16.8 thousand $\mathrm{CFU} / \mathrm{g}$ of soil. The accumulation of fungi in virgin soil may be due to a large accumulation of organic biomass, which activates the growth and development of fungi.

The greatest activity of cellulose-destroying microorganisms was observed in a layer of $0-20 \mathrm{~cm}$ on a variant of permanent wheat with herbicides and fertilizers (76.4 thousand CFU/g of soil), in comparison with virgin soil, which confirms their stimulating effect. In the remaining variants, the number of these microorganisms ranged from 55.5 to 58.4 thousand $\mathrm{CFU} / \mathrm{g}$ of soil.

The cellulose complex was represented by bacteria, fungi, and actinomycetes, the proportion of which was significant. The most active biological processes occur on the variant with mineral fertilizers. The mineral nitrogen from fertilizers serves as an additional source of nutrition for soil bacteria and its intensive reproduction. The immobilization of soil nitrogen into microbial biomass is characterized by increased amylolytic activity exceeding the other variants by 1.3-1.9 times (Table 6). The increased transformation coefficient $\left(\mathrm{C}_{\mathrm{pt}} 3.6\right)$ on the wheat monoculture variant with fertilizers and herbicides indicates an intensive transformation of plant residues into soil organic matter.

The studies have shown that in wheat crops with fertilizers and herbicides, the breakdown of fiber was maximal and amounted to $45.4 \%$ (Table
Table 6. Coefficients of transformation of soil organic matter

\begin{tabular}{|c|c|c|}
\hline Variants & $\begin{array}{l}\mathrm{C}_{\text {min* }} \\
\text { (SAAMPA) }\end{array}$ & $\begin{array}{c}\mathrm{C}_{\mathrm{pt}} \\
(\mathrm{MPA}+\mathrm{SAA}) \cdot(\mathrm{MPA} \mathrm{SAA}))\end{array}$ \\
\hline Virgin land & 3.4 & 3.5 \\
\hline $\begin{array}{l}\text { Perm. wheat without } \\
\text { fertilizers and herbicides }\end{array}$ & 5.1 & 3.5 \\
\hline $\begin{array}{l}\text { Perm. wheat with fertilizer } \\
\text { and herbicides }\end{array}$ & 6.7 & 3.6 \\
\hline Wheat on fallow land & 5.0 & 3.1 \\
\hline
\end{tabular}

5). The cellulolytic activity was significantly reduced on the variant of permanent wheat without fertilizers and herbicides in comparison with virgin soil. The decrease in the mass of linen was $21.5 \%$, which indicates a weak degree of decomposition of fiber. This can be explained by the fact that in the wheat crops without additional nitrogen supply to the soil, the process of cellulose decomposition is more inhibited [Koroleva et al., 2013].

In permanent wheat crops with fertilizers and herbicides, more active production of carbon dioxide was observed (2.61 with $2 \mathrm{~kg} /$ ha/hour), which indicates a more pronounced transformation of organic matter (Table 5). This fact may be explained by the stimulating effect of small doses of herbicides, which contributed to the active respiration of the soil [Zelles et al., 1985]. A slight excess of the $\mathrm{CO}_{2}$ emissions from virgin soils (3.0 C $2 \mathrm{~kg} / \mathrm{ha}$ /hour) is associated with a richer species composition of grasses, their higher aboveground, and underground masses and, as a consequence, a significant proportion of root respiration in the total flow of $\mathrm{CO}_{2}$ from the soil under natural vegetation [Chimitdorzhieva, 2017].

Table 7. Grain quality of permanent spring wheat and wheat on fallow land, the average for 2012-2014

\begin{tabular}{|c|c|c|c|c|c|c|c|}
\hline \multirow[b]{2}{*}{ Variants } & \multirow[b]{2}{*}{$\begin{array}{l}\text { Weight per } \\
\text { bushel, g/l }\end{array}$} & \multirow[b]{2}{*}{$\begin{array}{l}\text { Weight of } \\
1,000 \text { grains }\end{array}$} & \multirow[b]{2}{*}{$\begin{array}{c}\text { Vitreousness, } \\
\%\end{array}$} & \multicolumn{2}{|r|}{ Gluten } & \multirow[b]{2}{*}{ Class } & \multirow[b]{2}{*}{$\begin{array}{l}\text { Yield } \\
\text { c/ha }\end{array}$} \\
\hline & & & & $\%$ & $\begin{array}{l}\text { Fiber deformation } \\
\text { measurement } \\
\text { (FDM) units }\end{array}$ & & \\
\hline $\begin{array}{l}\text { Perm. wheat } \\
\text { without } \\
\text { chemicalization }\end{array}$ & $768 \pm 5$ & $36.6 \pm 0.5$ & $61 \pm 1$ & $30.2 \pm 0.1$ & $68 \pm 1$ & 1 & $7.0 \pm 2.4$ \\
\hline $\begin{array}{l}\text { Perm. wheat } \\
\text { with the use of } \\
\text { herbicides and } \\
\text { fertilizers }\end{array}$ & $803 \pm 4$ & $37.6 \pm 0.4$ & $68 \pm 1$ & $34.5 \pm 1.0$ & $75 \pm 1$ & 1 & $15.8 \pm 4.2$ \\
\hline $\begin{array}{l}\text { Wheat on fallow } \\
\text { land }\end{array}$ & $800 \pm 3$ & $36.3 \pm 0.2$ & $66 \pm 1$ & $30.4 \pm 0.3$ & $71 \pm 1$ & 1 & $17.6 \pm 5.1$ \\
\hline Average & $792 \pm 9$ & $37.0 \pm 0.3$ & $65 \pm 2$ & $31.8 \pm 1.0$ & $71 \pm 2$ & & \\
\hline $\mathrm{LSD}_{05}$ & 5 & 0.4 & 1 & 0.8 & 1 & & \\
\hline
\end{tabular}


The lowest carbon dioxide emission was observed in the wheat monoculture without the use of fertilizers and herbicides (1.61 with $2 \mathrm{~kg} / \mathrm{ha} /$ hour).

According to technological and commodity indicators of grain, the best option is the permanent sowing of spring wheat with fertilizers and herbicides (Table 7).

Almost all variants are distinguished by size (weight of 1,000 grains equaling 36.3-37.6 g), good weight per bushel results, except for permanent wheat without intensification (797-803 $\mathrm{g} / \mathrm{l}$ ), and vitreousness (61-68\%). As for the gluten content, its significant increase was noted in the variant with fertilizers, as well as a decrease in the variant of sowing on fallow in a two-field crop rotation. In general, it can be considered established that the quality of grain is improved with the help of nitrogen-phosphorus fertilizers.

\section{Statistical relationship with soil fertility parameters}

Statistically significant differences in humus content were noted between virgin land, permanent wheat, and wheat by fallow (Table 1). There were no differences in the humus content between the variants with permanent wheat without fertilizers and with fertilizers. The content of the labile part of humus, humic and fulvic acids in the virgin area exceeded the other variants (Table 2). In the variant with intensification elements and without fertilizers, no statistically significant differences in the group composition of humus were found. According to the content of nutrients (nitrogen, phosphorus), there is no difference between virgin land and permanent wheat without chemicalization.
Statistical analysis of the data revealed a strong correlation between the humus content and the number of soil fungi $(r=0.95 \pm 0.21$, the coefficient of determination $\mathrm{d}_{\mathrm{xy}}=0.90$ or $90 \%$ of the effect) (Table 8). Naturally, a direct correlation of a strong degree was revealed between the fungi complex and the group composition of humus (total and labile soil carbon, carbon of humic and fulvic acids). This fact is natural, since microscopic fungi, due to the presence of various hydrolytic enzymes, participate in the mineralization of organic residues. In addition, due to the synthesis and accumulation of melanin-like pigments in hyphae, fungi contribute to the active formation of soil humus and transformations of nitrogen compounds, which subsequently improves the structure of the soil [Liaudanskiene et al., 2021].

Humus content is directly related to the respiration of the soil. The more humus in the soil, the more carbon dioxide is released, which is also statistically confirmed $(\mathrm{r}=0.93 \pm 0.26$, determination coefficient $\mathrm{d}_{\mathrm{xy}}=0.86$ or $86 \%$ of the effect) (Table 8).

\section{CONCLUSIONS}

The results of three years of studies have shown that the main factor affecting the yield of spring wheat is the sufficient supply of nutrients, i. e. nitrate nitrogen and mobile phosphorus in the soil. The use of mineral fertilizers, herbicides, and fallow fields provide yields at the level of 15.0-17.0 c/ha compared with permanent wheat without chemicals yielding $7.0 \mathrm{c} / \mathrm{ha}$.

Table 8. The relationship between the parameters of soil fertility and indicators of microbiological activity

\begin{tabular}{|l|c|c|c|c|c|c|c|c|c|c|c|}
\hline \multicolumn{1}{|c|}{ Factor } & Humus & $\mathrm{C}_{\text {total }}$ & $\mathrm{C}_{\text {lab. }}$ & $\mathrm{C}_{\mathrm{gc}}$ & $\mathrm{C}_{\mathrm{fc}}$ & $\mathrm{MPA}$ & $\mathrm{SAA}$ & Fungi & Cellulolytics & $\mathrm{CO}_{2}$ & $\begin{array}{c}\text { Decomposition } \\
\text { of cellulose. }\end{array}$ \\
\hline Humus & 1 & & & & & & & & & & \\
\hline $\mathrm{C}_{\text {total }}$ & 1.00 & 1.00 & & & & & & & & & \\
\hline $\mathrm{C}_{\text {lab. }}$ & 0.95 & 0.95 & 1.00 & & & & & & & & \\
\hline $\mathrm{C}_{\mathrm{gc}}$ & 0.95 & 0.95 & 1.00 & 1.00 & & & & & & & \\
\hline $\mathrm{C}_{\mathrm{fc}}$ & 0.93 & 0.93 & 1.00 & 1.00 & 1.00 & & & & & & \\
\hline $\mathrm{MPA}$ & -0.03 & -0.03 & -0.31 & -0.29 & -0.37 & 1.00 & & & & & \\
\hline SAA & -0.46 & -0.46 & -0.68 & -0.68 & -0.67 & 0.48 & 1.00 & & & & \\
\hline Fungi & 0.95 & 0.95 & 0.98 & 0.98 & 0.98 & -0.33 & -0.54 & 1.00 & & & \\
\hline Cellulolytics & -0.10 & -0.09 & -0.27 & -0.25 & -0.34 & 0.89 & 0.11 & -0.38 & 1.00 & & \\
\hline CO 2 & 0.93 & 0.93 & 0.89 & 0.88 & 0.89 & -0.19 & -0.26 & 0.96 & -0.38 & 1.00 & \\
\hline $\begin{array}{l}\text { Decomposition } \\
\text { of cellulose }\end{array}$ & 0.25 & 0.24 & 0.45 & 0.45 & 0.44 & -0.31 & -0.95 & 0.27 & 0.13 & -0.02 & 1.00 \\
\hline
\end{tabular}


In the variants with the use of chemicalization agents, microbiological and biochemical processes are more intensive. This applies to both the processes of mineralization of organic matter, an increase in cellulolytic activity (the breakdown of fiber to 45), and emissions from 2 to 2.61 from 2 $\mathrm{kg} / \mathrm{ha} /$ hour. The humus state of soils depends on the removal and intake of nutrients into the soil. It was noted that the intensive process of mineralization on wheat by fallow provides a sufficient yield only due to the mineralization of humus and its group composition, and as a consequence of its low content in the soil (2.48\%).

An important role influencing the yield, organic matter of the soil, and its microbiological composition is played by various types of soil tillage. In authors' opinion, the studies conducted in Northern Kazakhstan on the complex effect of chemicalization agents and different types of soil tillage (no-till, minimal till) on the humus state of the soil and its microbiological activity are promising.

\section{Acknowledgments}

The study was carried out within the framework of Program No. BR10764908 "Development of an agricultural system for the cultivation of crops (grains, legumes, oilseeds, and industrial crops) using elements of cultivation technology, differentiated nutrition, plant protection products and equipment for cost-effective production based on a comparative study of various cultivation technologies for the regions of Kazakhstan" funded by the Ministry of Agriculture of the Republic of Kazakhstan.

\section{REFERENCES}

1. Akhmetov K.A. 1988. Field crop rotation productivity on the Southern Chernozems of North Kazakhstan. [in Russian] Available at: https://agris.fao.org/ agris-search/search.do?recordID=SU19890086395

2. Ayupov Z.Z., Anokhina N.S., Minnebayeva I.F., Rytseva N.G. 2009. Influence of agriculture biologization elements on the dynamics of labile humic substances, yield and grain quality of winter wheat. Vestnik OGU, 6(100), 537-539. [in Russian]

3. Chimitdorzhieva E.O. 2017. Carbon stocks in postagrogenic dry steppe soils of western Transbaikal. Aridnye ekosistemy, 23(3(72)), 59-65. [in Russian]

4. Committee for Technical Regulation and Metrology of the Ministry of Industry and Trade of the
Republic of Kazakhstan. 2002. ST RK 1054-2002. Grain. Methods for determining the quantity and quality of gluten in wheat using mechanized means. Astana. [in Russian]

5. Committee for Technical Regulation and Metrology of the Ministry of Industry and Trade of the Republic of Kazakhstan. 2006. ST RK 1564-2006. Determination of the main indicators of grain quality using infrared analyzers. Astana. [in Russian]

6. Committee of Standards, Measures and Measuring Instruments under the USSR Council of Ministers. 2001a. GOST 10840-64. Grain. Methods for performing the weight-per-bushel test. IPK Izdatel'stvo standartov, Moscow. [in Russian]

7. Committee of Standards, Measures and Measuring Instruments under the USSR Council of Ministers. 2001b. GOST 10987-76 Grain. Methods for determining vitreousness. IPK Izdatel'stvo standartov, Moscow. [in Russian]

8. Ershov Y.I. 2004. Organic matter of the biosphere and soil. Nauka, Novosibirsk, 104.

9. Fedorets N.G., Medvedeva M.V. 2009. Methodology for the study of soils in urbanized areas. Karelskii nauchnyi tsentr RAN, Petrozavodsk, 84. [in Russian]

10. Funakawa S., Nakamura I., Akshalov K., Kosaki T. 2004. Soil organic matter dynamics under grain farming in Northern Kazakhstan. Soil Science and Plant Nutrition, 50, 1211-1218.

11. Karabutov A.P., Tyutyunov S.I., Solovichenko V.D. 2019. Humus status of typical black soil under different intensity of arable land usage. EurAsian Journal of BioSciences, 13(2), 1317-1321.

12. Karbozova-Saljnikov E., Funakawa S., Akhmetov K., Kosaki T. 2004. Soil organic matter status of Chernozem soil in North Kazakhstan: Effects of summer fallow. Soil Biology \& Biochemistry, 36(9), 1373-1381. http://dx.doi.org/10.1016/j. soilbio.2004.02.027

13. Kenenbayev S.B., Yesenbayeva G.L. 2020. Adaptation of priority research direction in agriculture to climate change in Kazakhstan. International Journal of Agricultural Science and Food Technology, 6(1), 46-49.

14. Koroleva I.E., Lebedeva I.I., Grebennikov A.M. 2013. Gumusnoe i azotnoe sostoyanie tselinnykh pakhotnykh chernozemov [Humus and nitrogen state of virgin arable chernozems]. Bulletin of the Soil Institute named after V.V. Dokuchaev, 71, 27-35.

15. Kunanbayev K., Churkina G., Rukavitsina I., Filippova N., Utebayev M. 2019. Potential Attractiveness of Soil Fungus Trichoderma Inhamatum for Biodegradation of the Glyphosate Herbicide. Journal of Ecological Engineering, 20(11), 240-245.

16. Kunanbayev K.K. 2017. Group composition of soil organic matter in agrocenoses of Northern Kazakhstan. Agrofizika, 3, 27-33. 
17. Liaudanskiene I., Zukaitis T., Velykis A., Satkus A., Parasotas I. 2021. The impact of tillage practices on the distribution of humified organic carbon in a clay loam. Zemdirbyste-Agriculture, 108(1), 11-18.

18. Methodological guidelines for conducting a comprehensive agrochemical survey of agricultural soils. 2004. GU "Respublikanskii nauchno - metodicheskii tsentr agrokhimicheskoi sluzhby" MSKh RK, Nauchnyi, 91. [in Russian]

19. Mineev V.G., Ed. 2001. A practical course in agricultural chemistry: a manual, 2nd edition, revised and enlarged. Izd-vo MGU, Moscow, 689. [in Russian]

20. Pashkov S.V., Baibusinova S.B. 2017. Natural agrogenic conditionality of soil fertility in Northern Kazakhstan. Vestnik Zabaykal'skogo Gosudarvtsennogo Universiteta, 2, 15-27. [in Russian]

21. Polupan N.I. 1986. The nature and intensity of humus formation in the soils of the southern dry steppe of Ukraine under various anthropogenic influences. Agrokhimiya, 12, 62-72. [in Russian]

22. Raiesi F. 2021. The quantity and quality of soil organic matter and humic substances following dryfarming and subsequent restoration in an upland pasture. CATENA, 202, 105249.

23. Saparov A., Pachikin K., Mazhitovich M.B., Schindler U., Müller L., Eulenstein F. 2019. The current state of soil cover in Kazakhstan, problems and solution-Langfassung. Jahrestagung der DBG 2017: Horizonte des Bodens, Göttingen, Germany, 2-7 September 2017.

24. Sharkov I.N., Ed. 2010. Reproduction of humus as an integral part of the soil fertility management system. Rosselkhozakademiya. GNU Sib.NIIZiKh, Novosibirsk, 34. [in Russian]
25. Suleimenov M., Akhmetov K., Kaskarbayev Z., Kireyev A. 2005. Role of wheat in diversified cropping systems in dryland agriculture of Central Asia. Turkish Journal of Agriculture and Forestry, 29(2), 143-150.

26. Takata Y., Funakawa S., Akshalov K., Ishida N., Kosaki T. 2007. Influence of land use on the dynamics of soil organic carbon in northern Kazakhstan. Soil Science and Plant Nutrition, 53(2), 162-172. http:// dx.doi.org/10.1111/j.1747-0765.2007.00127.x

27. Takata Y., Funakawa S., Akshalov K., Ishida N., Kosaki T. 2008. Regional evaluation of the spatio-temporal variation in soil organic carbon dynamics for rainfed cereal farming in northern Kazakhstan. Soil Science and Plant Nutrition, 54(5), 794-806. http:// dx.doi.org/10.1111/j.1747-0765.2007.00298.x

28. Titova N.A., Kogut B.M. 1991. The transformation of organic matter in agricultural soil use. Pochvovedenie i agrokhimiya, 8, 3-156.

29. Toktar M., Koshen B.M., Shayakhmetova A.S., Kushenov B.M., Nurgaziev R. 2019. Dehumification of soils in the northern Kazakhstan region. International Multidisciplinary Scientific GeoConference: SGEM, 19(3.2), 109-116.

30. Vasiliev I.P., Tulikov A.M., Bezdyrev G.I. 2004. A practical course in agriculture. Kolos, Moscow, 424. [in Russian]

31. Voltr V., Menšík L., Hlisnikovsky L., Hruška M. 2021. The soil organic matter in connection with soil properties and soil inputs. Agronomy, 11(4), 779.

32. Zelles L., Scheundert I., Korte F. 1985. Side effects of some pesticides on non-target soil microorganisms. Journal of Environmental Science and Health, 20, 457-488. [in Russian] 